OSEANOLOGI DAN LIMNOLOGI DI INDONESIA

Print ISSN: 0125-9830 Online ISSN: 2477-328X

Nomor Akreditasi: 712/AU3/P2MI - LIPI/10/2015

http://jurnal-oldi.or.id

\title{
Difficulties in the Identification of Deep Sea Ophiuroidea Post-Larvae from Makassar Strait, Indonesia and Their Implication for Taxonomic Studies
}

\author{
Kesulitan Dalam Identifikasi Paska Larva Bintang Mengular Laut Dalam Dari Selat \\ Makassar, Indonesia dan Implikasinya Terhadap Kajian Taksonomi
}

\section{Supono}

Bitung Marine Life Conservation Unit-North Sulawesi, Research Centre for Oceanography LIPI

Email: supono@lipi.go.id,supono_lipi@yahoo.com

Submitted 20 January 2017. Reviewed 6 Juny 2017. Accepted 5 February 2018.

\begin{abstract}
Brittle stars (Ophiuroidea) are one of the most difficult groups to be classified among five classes of echinoderm fauna. This is due to the limited information on their growth and development. Most of information on morphological description and ecology of the identified species were derived from the adult shallow water brittle stars. Meanwhile, the deep sea brittle stars, particularly larval and postlarval stages are less documented due to lack of investigation. This study investigated morphological characteristics of brittle star postlarvae collected from the deep sea of Makassar Strait on 8-15 June 2013. Six individual postlarvae of brittle stars were recorded. The important morphological characteristics of these postlarvae were described as preliminary record for similar future studies. All postlarvae collected in this study demonstrated lack of important structures for identification. Therefore, genetic studies may need to be carried out to identify the samples up to species level.
\end{abstract}

Keywords: brittle star postlarvae, Ophiuroidea, deep sea, morphology.

\begin{abstract}
Abstrak
Bintang mengular (Ophiuroidea) adalah salah satu kelompok fauna yang sulit untuk diidentifikasi dari lima kelompok Ekhinodermata. Hal ini disebabkan karena informasi yang terbatas tentang tahap pertumbuhan kelompok bintang mengular. Sebagian besar informasi tentang ekologi dan deskripsi morfologi jenis yang sudah teridentifikasi berasal dari jenis bintang mengular dewasa dari perairan dangkal. Sementara itu, informasi tentang jenis bintang mengular laut dalam, terutama tahap pascalarva sangat sedikit dikarenakan penelitian yang terbatas. Penelitian ini mengamati karakteristik morfologi pascalarva bintang mengular yang dikoleksi dari 21 stasiun laut dalam di Selat Makassar pada 8-15 Juni 2013. Enam pascalarva bintang mengular ditemukan selama penelitian. Seluruh pascalarva yang diamati pada penelitian ini menunjukkan struktur penting yang tidak lengkap untuk proses identifikasi. Penelitian genetika diperlukan untuk mengidentifikasi seluruh sampel hingga ke tingkat spesies.
\end{abstract}

Kata kunci: pascalarva bintang mengular, Ophiuroidea, laut dalam, morfologi. 


\section{Introduction}

The deep sea floor represents a unique ecosystem with extremes of pressure, temperature, and food input (Sanders 1968). The limiting factors demonstrated in deep sea floors influence the productivity, abundance, physiological and morphological adaptations of organisms. In comparison with shallow water, deep sea ecosystems are poorly understood (Sanders 1968; Hochachka and Somero 1984; Merrett 1989; Levin and Gage 1998).

Echinoderms dominate the errant macrofauna of the deep sea benthos with brittle stars (Ophiuroids) are particularly abundant (Gage and Tyler 1991). The use of skeletal elements for taxonomic identification of ophiuroids has led to a significant increase in the discovery of new species from the 18th century to present (Stöhr et al. 2012).

Despite the high abundance of ophiuroids, they are difficult to classify because of limited information on ontogeny (Clark 1911). Of the 2,064 listed and identified brittle stars from both shallow and deep waters (Stöhr et al. 2012), less than 30 species of postlarvae have been identified (Muus 1981; Turner and Miller 1988; Sumida et al. 1998).

Recently, 50 juveniles of brittle stars have been successfully described using the combination of external and internal skeletal characteristics such as jaws and dental plates (Sumida 1998; Stöhr 2005). Postlarvae of brittle stars are lack of important adult characteristics for identification, making species identification difficult (Turner and Miller 1988).

Makassar Strait, a deep waterway covering several islands including Laut and Sebuku Islands divides Sulawesi and Kalimantan Islands of Indonesia extending 130 to $370 \mathrm{~km}$ wide (Rositasari 2010). This strait features three distinct water columns of $200 \mathrm{~m}$, $300 \mathrm{~m}$, and 1,600 m depth (Woworuntu et al. 2001). The topography of Makassar Strait extends from the shallow 5 to $10 \mathrm{~m}$ slope of the Mahakam delta to more than 2,500 m depth off shore. The muddy bottom sediment (Helfinalis
2010), its topography relief and sedimentation reveal the unique composition of its benthic fauna.

The diversity of deep sea echinoderm, particularly Ophiuroids, in Indonesia is poorly understood. Most of recent available studies on brittle stars in Sulawesi water have focused more on shallow water species as part of echinderm studies (Darsono and Aziz 2002; Supono and Manik 2013; Katili 2011; Tahe et al. 2013; Supono et al. 2014; Yusron 2016; Nurdiansah and Supono 2017). Only few studies has reported deep sea ophuroids but none of them described the diversity of ophiuroids in Makassar Strait (Guille and Wolff 1984; Jangoux and Ridder 1987). This paper aims to describe the important morphological characteristics of the deep sea brittle stars (Ophiuroid) postlarvae from Makassar Strait based on preliminary identification.

\section{Methodology}

The study was carried out in 21 stations of Makassar Strait representing a range of depths (Figure 1, Table 1). Samples of brittle stars were collected using a $60 \times 50 \mathrm{~cm}$ box corer. As this study was part of different research group i.e. macro-benthic, biogeochemical aspects, and microbiology, samples were further sorted from sediment samples by collecting only the top 2 $\mathrm{cm}$ of the surface layer, sieved using $300 \mu \mathrm{m}$ mesh modified from Sanders et al. (1965) and Rex (2102) and post-larvae were separated from the sieved material with a binocular microscope. To avoid the damage of body parts from preservation (alcohol 96\%), samples were first treated with $\mathrm{MgCl}_{2}$ before preserving for further observation. Specimens of brittle stars were then morphologically observed under a microscope.

Specimens of brittle stars were then morphologically observed under 400x magnification of compound microscope. Preliminary examination was carried out following the criteria reported by Sumida (1998) as presented in Figure 2. 


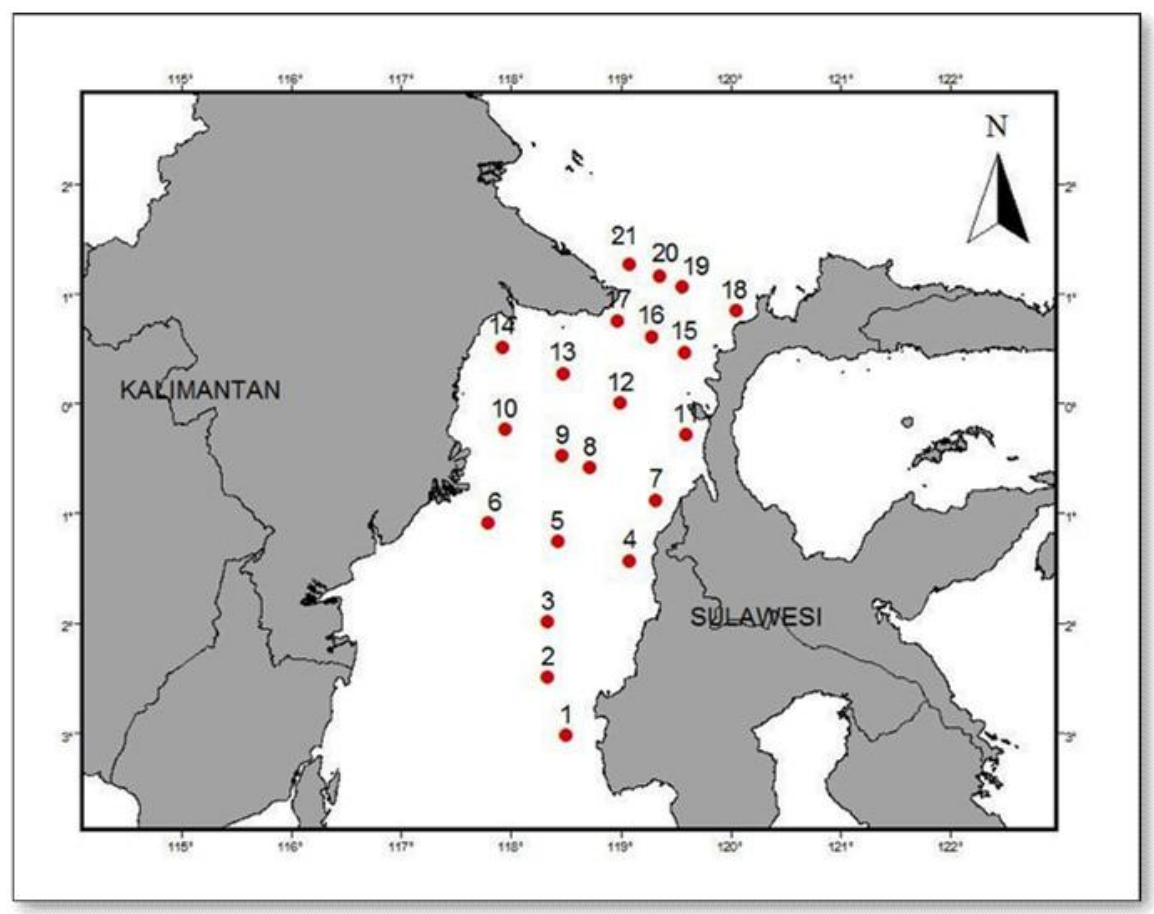

Figure 1. Map of sampling location.

Gambar 1. Peta lokasi pengambilan sampel.

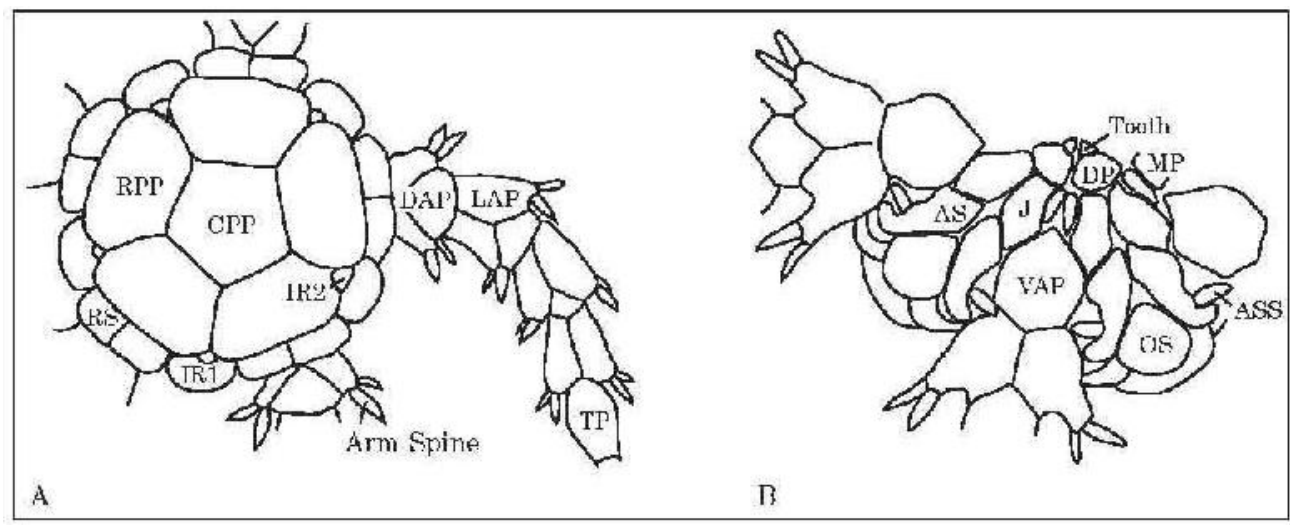

Figure 2. Main structures of ophiuroid postlarvae. A). Dorsal view, B). Ventral view. CPP $=$ Central Primary Plate, $\mathrm{RPP}=$ Radial Primary Plate, $\mathrm{IR}=$ Interradial plate, $\mathrm{RS}=$ Radial Shield, $\mathrm{DAP}=$ Dorsal Arm Plate, LAP $=$ Lateral Arm Plate, TP $=$ Terminal Plate, VAP $=$ Ventral Arm Plate, OS = Oral Shield, AS = Adoral Shield, ASS = Adora Shield Spine, $\mathrm{J}=\mathrm{Jaw}, \mathrm{DP}=$ Dental Plate, MP = Mouth Papilla (Sumida 1998).

Gambar 2. Struktur utama pascalarva bintang mengular. A). Tampak atas, B). Tampak bawah.

Table 1. Time and location of recorded samples.

Tabel 1. Waktu dan lokasi pengambilan sampel.

\begin{tabular}{|c|c|c|c|c|c|}
\hline Station & Date & Number of samples recorded & Latitude & Longitude & Depth (m) \\
\hline 2 & $09 / 06 / 2013$ & 1 & $\mathrm{~S} 2^{\circ} 30.018^{\prime}$ & E $118^{\circ} 20.255^{\prime}$ & 2145 \\
\hline 9 & $11 / 06 / 2013$ & 1 & S $0^{\circ} 28.910^{\prime}$ & E $118^{\circ} 28.382^{\prime}$ & 2375 \\
\hline 18 & $15 / 06 / 2013$ & 1 & $\mathrm{~N} 0^{\circ} 50.405^{\prime}$ & E $120^{\circ} 03.503^{\prime}$ & 1277 \\
\hline 21 & $16 / 06 / 2013$ & 3 & $\mathrm{~N} 1^{\circ} 16.180^{\prime}$ & E $119^{\circ} 05.253^{\prime}$ & 1359 \\
\hline
\end{tabular}




\section{Results}

During investigation, six postlarvae of brittle stars were recorded from four stations out of 21 total stations investigated. Based on morphological characteristics, the specimens were found in two stages consisted of two individuals of early-postlarvae and four individuals of the more developed postlarvae. Each specimen was presented based on reference collection number, station, depth, and view. The early larval stage demonstrated an undeveloped body structure (Figure 3A-B). Specimen 3A-B (LBRCO00265) demonstrated a disc diameter of $2.2 \mathrm{~mm}$ and not welldeveloped arms. This specimen was possibly an early stage of postlarvae which lacked most of main characteristics for identification. Specimen 3C-D (LBRCO00262) demonstrated a disc diameter of $1 \mathrm{~mm}$ (Figure 3C-D). The disc was highly swollen and surrounded by five RPPs. Despite the clearly defined structure of body parts, ornamentation on each body part such as disc rosette, arm spine type, and dental plate on the ventral side were absent.

$$
\text { Figure } 5 \mathrm{~A}-\mathrm{B}
$$

demonstrated a $1.5 \mathrm{~mm}$ pentagonal disc and a clear defined CPP, while Figure 5C-D (LBRCO00278) demonstrated a $1 \mathrm{~mm}$ highly swollen disc surrounded by five RPPs.
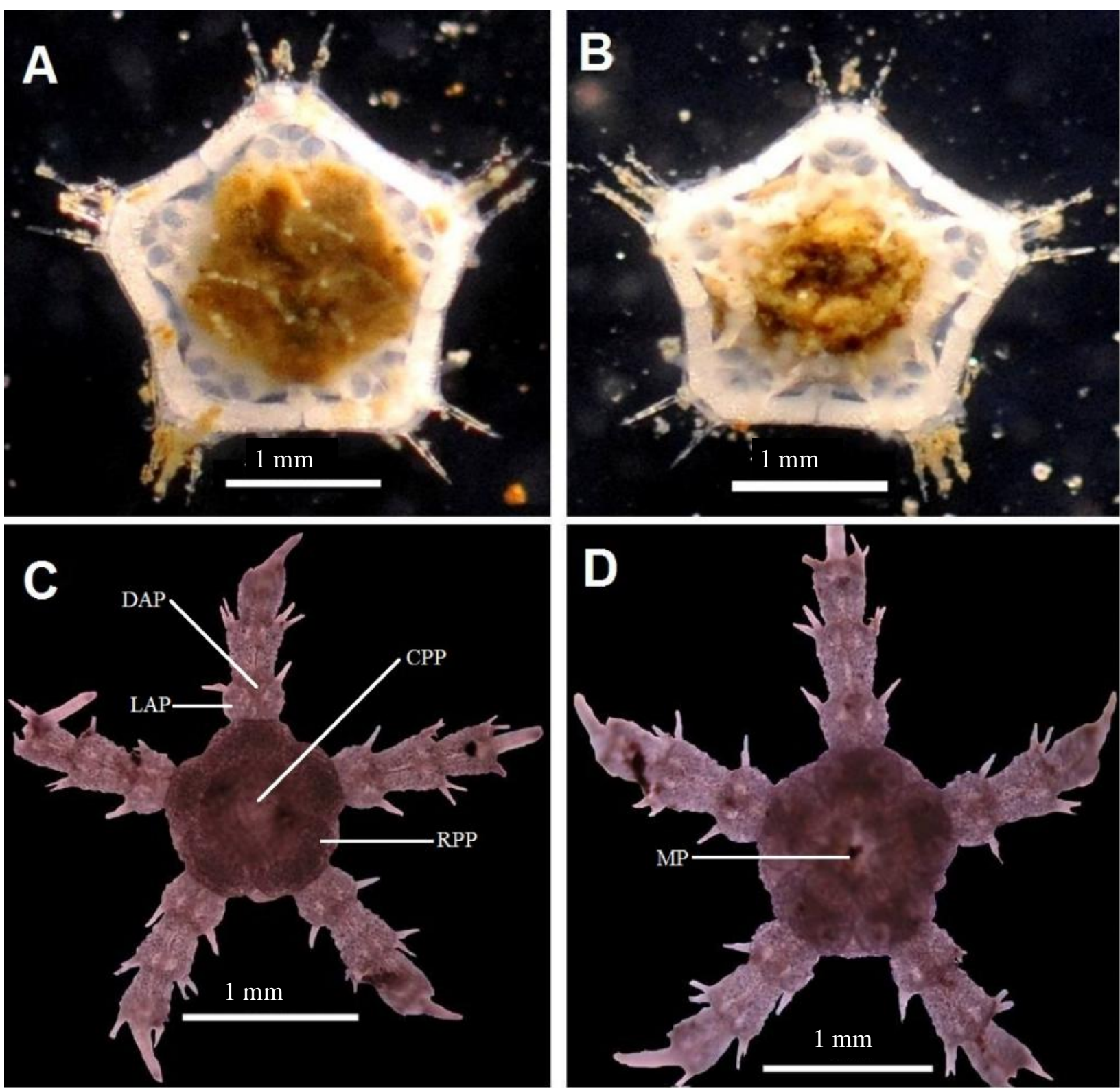

Figure 3. A-B. LBRCO00265, st9/1334 m, C-D. LBRCO00262. st2/2145 m. Dorsal (left) and ventral (right) view.

Gambar 3. A-B. LBRCO00265, st9/1334 m, C-D. LBRCO00262. st2/2145 m. Tampak atas (kiri) dan tampak bawah (kanan). 

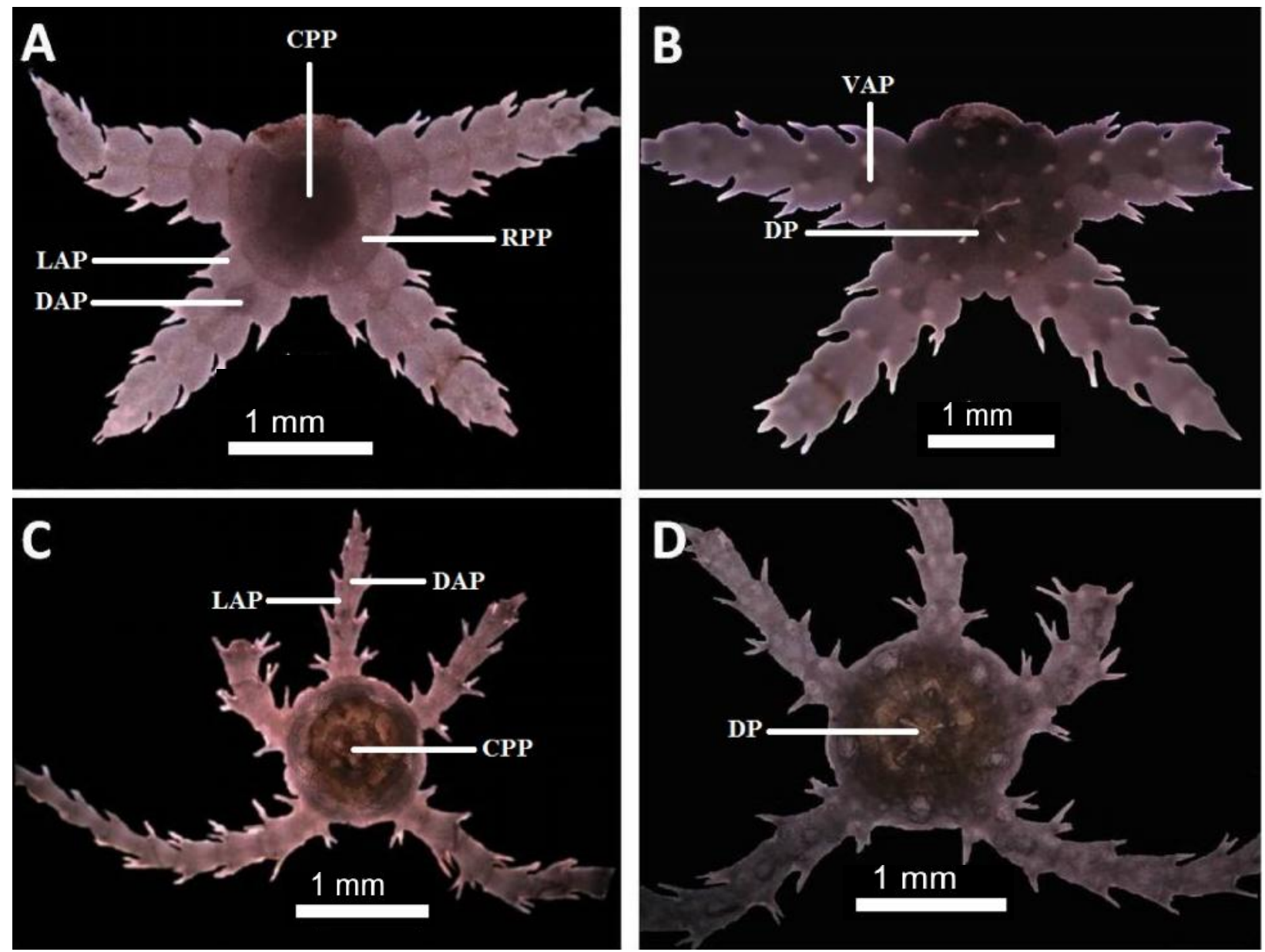

Figure 4. A-B. LBRCO00268 (st21/875 m), C-D. LBRCO00278 (st18/1277 m). Dorsal (left) and ventral (right) view.

Gambar 4. A-B. LBRCO00268 (st21/875 m), C-D. LBRCO00278 (st18/1277 m). Tampak atas (kiri) dan tampak bawah (kanan).
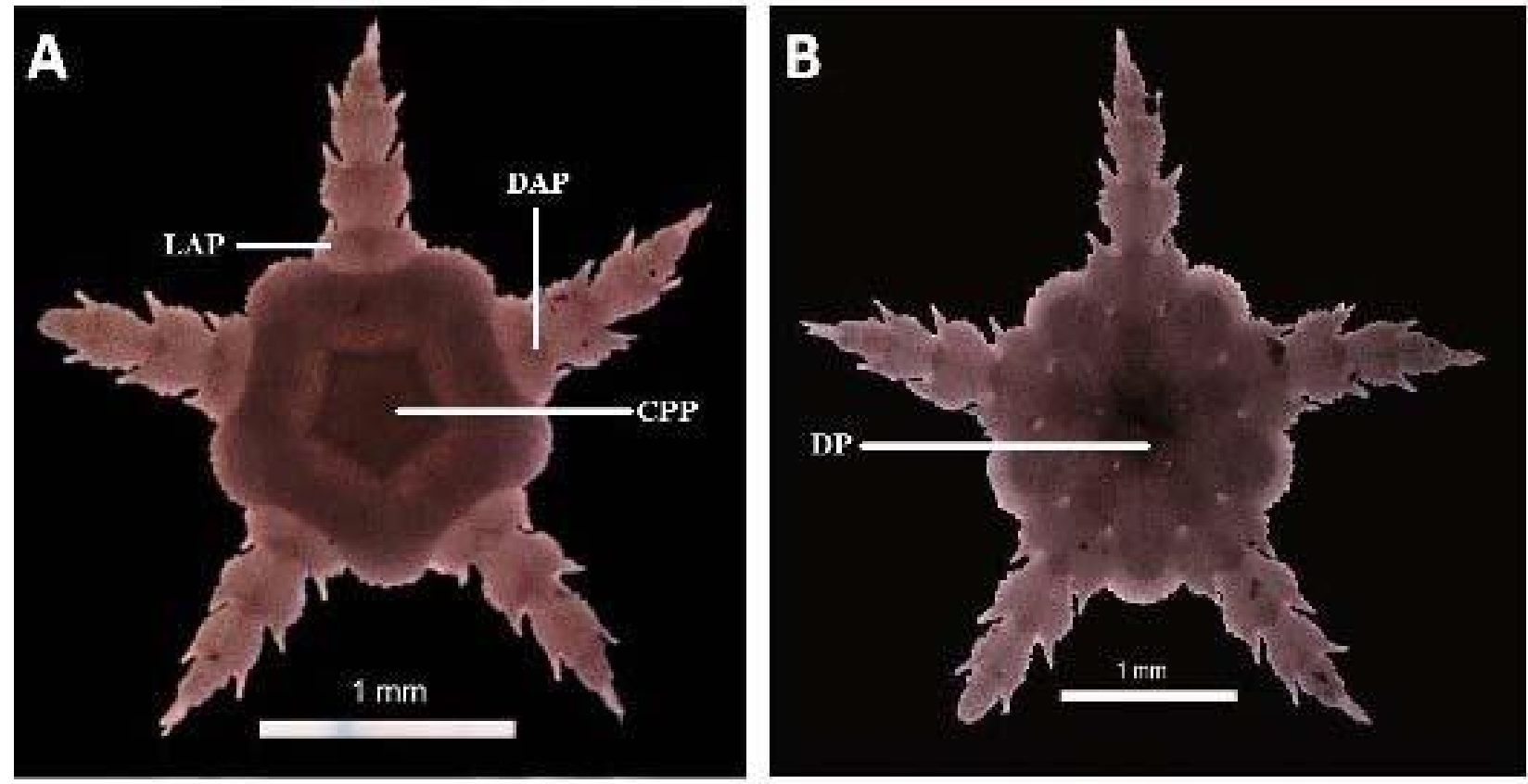

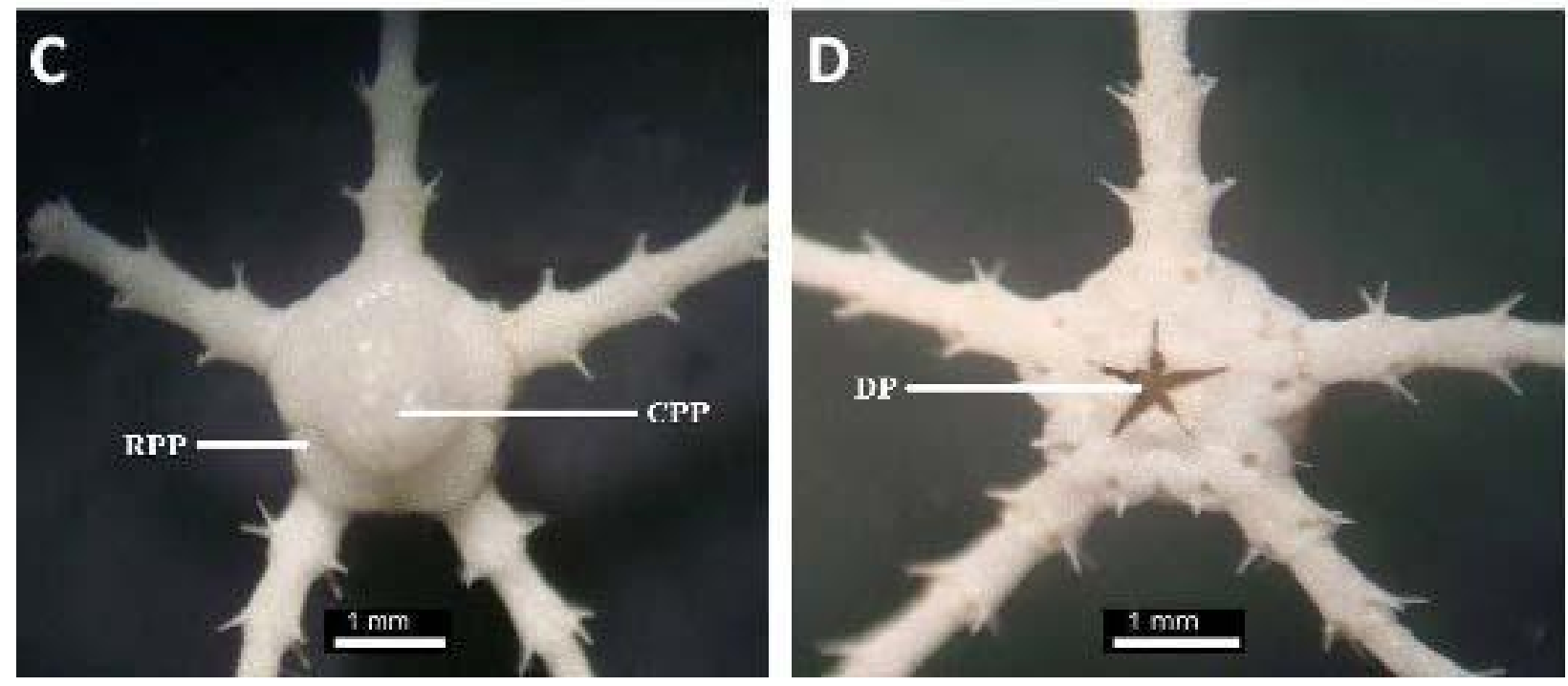

Figure 5. A-B. LBRCO00269 (st21/875 m), C-D. LBRCO00278 (st21/1359 m). Dorsal (left) and ventral (right) view.

Gambar 5. A-B. LBRCO00269 (st21/875 m), C-D. LBRCO00278 (st21/1359 m). Tampak atas (kiri) dan tampak bawah (kanan).

\section{Discussion}

Postlarval stages of echinoderms are important to resolve phylogeny in this phylum (Fell 1936). Deep sea brittle star population are often dominated by a large proportion of immature specimens (Schoener 1967). Thus, it is important to understand the intraspecific form development during the growth of brittle stars in order to identify postlarval stages.

Postlarvae of ophiuroids collected in this study were morphologically not well-developed. Despite the clear definition of some important characteristics such as central primary plate, mouth papilla, and arm segmentation, most of postlarvae demonstrated unclear arm ornamentation, terminal arm plate, dental plate, spinelets and ventral side structure and ornamentation, which are other important characteristics for identification to species. All of these morphological characteristics are important to distinguish closely related species within the same genus (Schoener 1967; Schoener 1969; Muus 1981).

The morphological characteristics of ophiuroids in the recent study were insufficient to describe even up to family level. In general, there are at least 15 main morphological characters to aid identification at family level (Clark and Rowe 1971). All of these characters, such as arm (branching, bending, insertion, spines, dorsal arm plate), body surface, ornament on disc scale, vertebrae (ventral furrow, articulation), tooth (infradental papillae, oral papillae), second oral tentacle pore and articulation between radial shield and genital plates, are essential characters to distinguish among families (Clark and Rowe 1971). For instance, the presence of oral papillae in Ophionereididae and Ophiocomidae is not the case in Ophiothrichidae. On the other hand, Ophiothricide and Ophiocomidae share similar structure of tooth on the dental plate, while Ophionereididae demonstrates different structure of tooth (Clark and Rowe 1971).

Among six post-larvae described in this study, only one specimen (LBRCO00278, Figure 5C-D) demonstrates the most developed morphological structures. The most distinctive characteristic of this specimen is high disc with domed pentagonal CPP. Similar feature of domed pentagonal CPP has been previously reported by Stöhr (2005) on the family of Ophiuridae. In Ophiura group, high domed CPP is surrounded by almost imperforate border (Stöhr 2005), which is also demonstrated by specimen in this study. Some post-larvae of Ophiura group demonstrate swollen LAP e.g. Ophiura ophiura, which is not the case of specimen LBRCO00278. This specimen shows elongated rectangular LAP resembling $O$. ljungmani as reported by Schoener (1967). While some characteristics of specimen LBRCO00278 resembles closely to the family of Ophiuridae, identification to genus or species level is not possible due to the lack of some important charachteristics.

Our findings were inadequate to present a comprehensive description for taxonomical purposes. The difficulty in sample handling 
during microscopic observation is due to small body size and fragile structure. These are further constraint after inadequate individual number collected during the study. The difficulties in the identification of deep sea ophiurid post-larvae will reduce the pace of new species discovery. As has been described earlier in the introduction, deep sea ecosystem is dominated by ophiuroids (Gage and Tyler 1991) with large proportion of immature species (Schoener 1967). The success of post-larval identification will increase the number of known species in Indonesia.

\section{Conclusion}

Morpological characteristics of ophiuroid post-larvae in this study represents difficulty for spesies identification. Post-larval body structure, size and individual number recorded are insufficient to further identification in species level. Future research will include the use of different sampling methods to increase the number of collected individual, Scanning Electron Microscope (SEM) for better microscopic description and molecular studies to aid identification into species level, particularly for undeveloped post-larvae.

\section{Acknowledgement}

This study would not have been possible without financial and logistic support during Widya Nusantara Expedition 2013 funded by the Research Center for Oceanography, Indonesian Institute of Sciences. We would like to thank Indra Bayu Vimono and Ucu Yanu Arbi for the support in sorting out the samples from sediments.

\section{References}

Barnett, P. R. O., J. Watson, and D. Connelly. 1984. A mutiple corer for taking virtually undisturbed samples from shelf, bathyal and abyssal sediments. Oceanol. Acta 7: 399-408.

Boos K., L. Gutow, R. Mundry, and H. D. Franke. 2010. Sediment preference and burrowing behaviour in the sympatric brittlestars Ophiura albida Forbes, 1839 and Ophiura ophiura (Linnaeus, 1758) (Ophiuroidea, Echinodermata). Journal of Experimental Marine Biology and Ecology 393: 176-181.

Clark, S. H. 1911. North Pacific ophiurans in the collections of the United States National Museum. Bulletin of the United States National Museum 75: 1-302.

Darsono, P., and A. Aziz. 2002. Komunitas ekhinodermata dari beberapa pulau di daerah
Sulawesi Utara. Majalah Ilmu Kelautan, 26(7): 77-88.

Fell, H. B. 1963. The evolution of the echinoderms. Ann. Rep. Smithsonian Inst: 457-490.

Gage, J. D., and P. A. Tyler. 1981. Re-appraisal of age composition, growth and survivorship of the deep-sea brittle star Ophiura ljungmani from size structure in a sample time series from the Rockall Trough abyssal. Maret. Biol. 64: 163-172.

Gage, J. D., and P. A. Tyler. 1982. Depth-related gradients in size structure and the bathymetric zonation of deep-sea brittle stars. Marine Biology 71: 299-308.

Gage, J. D., and P. A. Tyler. 1991. Deep sea biology: a natural history of organisms at the deep sea floor. In P. A. Tyler, C. M. Young and A. Clarke (Eds) Temperature and pressure tolerances of embryos and larvae of the Antarctic sea urchin Sterechinus neumayeri (Echinodermata: Echinoidea): Potential for deep sea invasion from high latitudes. Marine Ecology Progress Series 192: 173-180.

Guille, A., And W. J. Wolff. 1984. Resultats biologiques de I'Expedition Snellius. Echinodermata. Ophiuroidea. Zool. Verb. Leiden 213 (5): 1-39

Helfinalis 2010. Pengaruh Mahakam delta terhadap padatan tersuspensi di kolom air dan pengendapan sedimen didasar perairan selat Makassar. Edisi Khusus Lingkungan Tropis: 123-132.

Hendler, G. 1975. Adaptational significance of the patterns of ophiuroid development. American Zoologist 15: 691-715.

Hendler, G. 1991. Ophiuroidea. In S., Stöhr, T. D., O'Hara \& B Thuy (Eds) Global diversity of brittle stars (Echinodermata: Ophiuroidea). PLos ONE 7(3): 1-14.

Hessler, R. R., and P. A. Jumars. 1974. Abyssal community analysis from replicate box cores in the central North Pacific. Deep Sea Res 21: 185-209.

Hochachka. P. W., and G. N. Somero. 1984. Biochemical adaptation. Princeton University Press, Princetonm NJ. 537pp.

Jangoux, M., and C. D. Ridder. 1987. Anotated catalogue of recent echinoderm type specimens in the collection of the Rijksmuseum Van Natuurlijke Historie at Leiden. Zoologische Mededelingen 61(6): 79-96.

Jones, M. B., and G. Smaldon. 1989. Aspects of the biology of a population of the cosmopolitan brittlestars Amphipholis 
Squamata (Echinodermata) from the Firth of Forth, Scotland. Journal of Natural History 23: 613-625.

Katili, A. S. 2011. Struktur komunitas echinodermata pada zona intertidal di Gorontalo. Jurnal Penelitian dan Pendidikan, 8(1): 51-61.

Levin, L. A., and J. D., and Gage. 1998. Relationships between oxygen, organic matter and the diversity of bathyal macrofauna. Deep-Sea Res. II, 45: 129-163.

Menzies, R. J., R. Y. George, and G. T. Rowe. 1973. Abyssal environment and ecology of the world oceans. In S. Stöhr, T. D. O'Hara \& B. Thuy (Eds) Global diversity of brittle stars (Echinodermata: Ophiuroidea). PLos ONE 7(3): 1-14.

Merret, N. 1989. Fishing around in the dark. New Sci.121: 50-54.

Montagne, P. A., J. G. Baguley, C. Y. Hsiang and M. G. Reuscher. 2016. Comparison of sampling methods for the deep-sea infauna. Limnology and Oceanography: Methods: 118.

Muus, K. 1981. Density and growth of juvenile Amphiura filiformis (Ophiuroidea) in the Øresund. Ophelia 20: 153-168.

Nurdiansah, D., and Supono. 2017. Keanekaragaman bintang mengular (Ophiuroidea) di perairan Pulau Talise, Sulawesi Utara. Jurnal Ilmu dan Teknologi Kelautan Tropis 9(2):709-716.

Rex, M. A. 1981. Community structure in the deep-sea benthos. Ann. Rev. Ecol. Syst. 12: 331-353.

Rositasari, R. 2010. Recent foraminiferal communities in Makassar strait. Journal of Coastal Development 14(1): 26-34.

Sanders, H. L., R. R. Hessler and G. R. Hampson. 1965. An introduction to the study of deep-sea benthic faunal assemblages along the Gay Head-Bermuda transect. Deep-sea. 12: 845-867.

Sanders, H. L. 1968. Marine benthic diversity: a comparative study. Am. Nat, 1-2: 243-282.

Schoener A. 1967. Post-larval development of five deep-sea ophiuroids. Deep-Sea Research 14: 645-660.

Schoener, A. 1969. Atlantic ophiuroids: some post-larval forms. Deep-Sea Res, 16: 127140.

Stöhr, S., T. D. O'Hara, and B. Thuy. 2012. Global diversity of brittle stars (Echinodermata: Ophiuroidea). PLos ONE 7(3): 1-14.

Stöhr, S. 2005. Who's who among baby brittle stars (Echinodermata: Ophiuroidea): postmetamorphic development of some North Atlantic Forms. Zoological Journal of The Linnean Society 143: 543-576.

Sumida, P. Y. G. 1998. Post-larval development in deep-sea echinoderms. Thesis. University of Southampton, United Kingdom. 297 pp.

Sumida, P. Y. G., P. A. Tyler, J. D. Gage, and A. Nørrevang. 1998. Postlarval development in shallow and deep-sea ophiuroids (Echinodermata: Ophiuroidea) of the NE Atlantic Ocean. Zoological Journal of the Linnean Society 124: 267-300.

Supono and N. Manik. 2013. Komunitas ekhinodermata di perairan Tagulandang, Sulawesi Utara. Oseanologi dan Limnologi di Indonesia 39(2): 85-94.

Supono, D. J. W. Lane and Susetiono. 2014. Echinoderm fauna of Lembeh Strait, North Sulawesi: Inventory and Distribution review. Mar. Res. Indonenesia 39(2): 51-69.

Tahe, O. S., Langoy, M. L. D., Katili, D. Y. and Papu, A. 2013. Keanekaragaman echinodermata di pantai Tanamon, Kecamatan Sinonsayang Sulawesi Utara. Jurnal Bios Logos 3(2): 65-72.

Turner, R. L., and J. E. Miller. 1988. Postmetamorphic recruitment and morphology of two sympatric brittlestars. In S. Stöhr (Eds) Who's who among baby brittle stars (Echinodermata: Ophiuroidea): postmetamorphic development of some North Atlantic Forms. Zoological Journal of The Linnean Society 143: 543-576.

Woodley, J. D. 1975. The behavior of some amphiurid brittle stars. Journal of Experimental Marine Biology and Ecology 18: 29-46.

Woworuntu, J. M., S. L. Garzoli, and D. B. Olson. 2001. Dynamics of Makassar strait. J. Mar. Research 59: 313-325.

Yokoyama, L. Q., and A. C. Z. Amaral. 2008. The diet of Ophionereis reticulate (Echinodermata: Ophiuroidea) in southeastern Brazil. Revista Brasileira de Zoologia 25: 576-578.

Yusron, E. 2016. Struktur komunitas ekhinodermata (Asteroidea, Ophiuroidea, Echinoidea dan Holothuroidea) di Perairan Taman Nasional Wakatobi Sulawesi Tenggara. Jurnal Ilmu dan Kelautan Tropis 8(1): 357-366.

Zimmerman, K. M., S. E. Stancyk, and L. A. J. Clements. 1988. Substrate selection by the burrowing brittlestar Microphiopholis gracillima (Stimpson) (Echinodermata: Ophiuroidea). Mar. Behav. Physiol. 13: 239255. 